\title{
Bergsoniana
}

1 | 2021

Reassessing Bergson

\section{Mis/Reading Bergson - On Time and Life and Matter}

Suzanne Guerlac

\section{(2) OpenEdition \\ Journals}

Electronic version

URL: https://journals.openedition.org/bergsoniana/345

DOI: 10.4000/bergsoniana.345

ISSN: 2800-874X

Publisher

Société des amis de Bergson

\section{Electronic reference}

Suzanne Guerlac, "Mis/Reading Bergson - On Time and Life and Matter", Bergsoniana [Online], 1 । 2021, Online since 01 July 2021, connection on 08 November 2021. URL: http://

journals.openedition.org/bergsoniana/345 ; DOI: https://doi.org/10.4000/bergsoniana.345

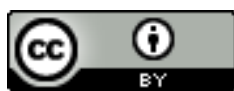

Les contenus de la revue sont mis à disposition selon les termes de la Licence Creative Commons Attribution 4.0 International. 


\title{
MIS/READING BERGSON- ON TIME AND LIFE AND MATTER
}

\author{
Suzanne GUERLAC
}

Because of the nature of his project, perhaps, and the requirements for writing it imposed, Bergson's thought has not only been appropriated by various Bergsonisms, but it has also often been misread, by critical and sympathetic readers alike. I'd like to sketch out a few mis-readings of his work and consider whether they might, in the end, prove productive.

In his influential essay on Baudelaire, Walter Benjamin famously charged that Bergson "rejects any historical determination of memory," thereby managing to "stay clear of that experience from which his own philosophy evolved, or rather, in reaction to which it arose [...] the blinding age of bigscale industrialism" (Benjamin 1968, 157). Benjamin was rehearsing the standard Frankfurt School view of Bergson when he refers to "the durée from which death has been eliminated" (Benjamin 1968, 185). In his 1934 essay, "La métaphysique bergsonienne du temps," Max Horkheimer criticised Bergson for not putting metaphysics "in dialectical relation with history” (Horkheimer 1983, 21). ${ }^{1}$ Bergson's philosophy, Horkheimer writes, is "bound to fail [devait échouer]" (Horkheimer 1983, 18), because it ignores human history, relying on intuition in the place of philosophical operations of determinate negation. Substituting duration for the dialectical concept of development, Horkheimer writes, "Bergson, unintentionally, abstracts out 'real' time and negates it [le nie]" (Horkheimer 1983, 19). In his celebrated formulation (to which Benjamin alludes) Bergson's metaphysics "makes

1. All translations of Merleau-Ponty (1967), Horkheimer (1983) and Soulez (1983) are mine. 
death disappear [fait disparaître la mort]" (Horkheimer 1983, 20). Instead of taking historical knowledge as his point of departure, Bergson starts from a scientific perspective, Horkheimer affirms, alluding not to Bergson's interest in mathematics and physics but to the treatment of the natural sciences in the context of German romanticism. What is needed, he maintains, is a Hegelian logic which "lets the negative act" (Horkheimer 1983, 21), a negativity he identifies with "the distress of individuals" (Horkheimer 1983, 21). This is to approach Bergson from a Hegelian perspective. As Philippe Soulez has pointed out, "for Horkheimer, to think time can only mean to situate oneself in a horizon of dialectic" (Soulez 1983, 5). Moreover, he maintains, the Frankfurt School analysis depends upon a reading of Hegel that separates Hegel's philosophy of history from his philosophy of nature. Alluding to the interpretations of Kojève and the early Sartre, Soulez writes: "For a certain generation, formed by a certain reading of Hegel, the specificity of Bergsonian discourse, namely a philosophy of the history of nature that does not yield a human philosophy, is unthinkable" (Soulez $1983,5)$. The human individual lies at the centre of philosophical reflection in the Frankfurt School context, where the individual is thought in relation to death. A "work of reason [travail rationnel] undertaken for the purpose of combatting death," Horkheimer insists, lies at the heart of the historical project of emancipation - the project of "bringing about a happier humanity [instaurer une humanité plus heureuse]" (Horkheimer 1983, 21). This work of reason, Horkheimer maintains, not only implies, but requires, a "mastery of reality by spirit/reason [l'esprit]" (Horkheimer 1983, 25).

Frankfurt school thinkers have been a crucial philosophical reference for invaluable social projects that concern justice and human rights throughout the $20^{\text {th }}$ century. But today, in the $21^{\text {st }}$ century, we are compelled to consider a new set of conditions, circumstances which are directly related to the humanist program of progress that Horkheimer advanced. The mastery of reality by spirit/reason [l'esprit] entailed a mastery of nature that has led us into the age of the Anthropocene. Today we think death most urgently not in relation to the solitude and misery of the individual, or even in relation to war and genocide, but in relation to mass extinction and Earth crisis. The project of mastery - the ideology of progress so compatible with Hegelian logic and Marxist thought, as well as civilisation discourses - has led to the precarity of the very conditions of life on this planet. If a philosophy predicated on death - the work of the negative - propelled a century of social change, today we need to also think about 
shared conditions of life - or livingness. I wonder whether, more than 80 years after his essay, Horkheimer's charge that Bergson's is a philosophy of duration, not development, might not be viewed as an opportunity instead of a weakness: can we look to Bergson to inspire, or support, what some now call a post-development, which is to say post-capitalist, thinking (see Massumi 2018; Read and Alexander 2019)?

Were it not for the urgency that confronts us - how to think in the face of today's planetary crisis - we might just thank Deleuze for making Bergson readable again by valorising nondialectical and non-humanist features of his thought, and for correcting Horkheimer's view that Bergson's metaphysics denies real time. But as temperatures rise, and species disappear, it is not Deleuze (or Deleuze-Bergson) that inspires, but Whitehead who wrote: "The doctrine that I am maintaining is that neither physical Nature nor life can be understood unless we fuse them together as essential factors in the composition of 'really real' things whose interconnections and individual characters constitute the universe" (Whitehead 1934, 57). The Deleuzian emphasis on ontology risks, as Horkheimer put it against Bergson, unintentionally abstracting out "real" time and life. Aiming toward what Whitehead calls the "really real," I turn not to Deleuze but to MerleauPonty's lectures on Nature (1955-60), which, I will try to show, misread Bergson when they explicitly take up his thought, but do so within a broader argument that is not only haunted by Bergson but, more importantly, can refresh and enliven our reading of Bergson, moving us away from Horkheimer's position (alive and well in some quarters) and also from the Horkheimer/Deleuze alternative and the Bergson-Deleuze hybrid.

Whereas Deleuze portrayed Bergson as an anti-philosopher, which had the effect of isolating him, Merleau-Ponty integrates him into a history of reflections on, and interrogations of, the concept of nature. His first mention of Bergson comes in connection with Schelling: "in one sense," Merleau-Ponty writes, "all is interior to us, in another sense we are in the Absolute (cf. Bergson). This reciprocity is possible because we are no longer in a philosophy of Being [...] we are in a philosophy of time" (Merleau-Ponty 2003, 48). Merleau-Ponty challenges Hegel's critique of Schelling (which parallels Horkheimer's critique of Bergson) and, when he turns his focus to Bergson, designates his thought a Naturphilosophie because of its intuition of a primordial ground, one Merleau-Ponty associates with Schelling's Erste Natur, "the fundamental stuff of all life, and of every existing being" (Merleau-Ponty 2003, 38). Alluding to (but 
not citing) Bergson's famous opening line of Matter and Memory "Here I am in the presence of images, in the vaguest sense of the word, images perceived when my senses are open to them, unperceived when they are closed [Me voici donc en présence d'images, au sens le plus vague où l'on peut prendre ce mot, images perçues quand jouvre mes sens, inaperçues quand je les ferme]" (Bergson 1988, 17; 2012, 11) — he posits nature as a "common medium of being and perception" (Merleau-Ponty 2003, 56) - as primordial ground in this sense — and defines perception as "a fundamental act that installs us in the things" of nature (Merleau-Ponty 2003, 53). Acknowledging that "we here guess at, more than we grasp, the thought of Bergson" (Merleau-Ponty 2003, 55), Merleau-Ponty proceeds to leave nature philosophy aside and to translate the nuanced argument of Bergson's Matter and Memory (pace Horkheimer) into the dialectical terms of Sartre's phenomenal ontology. "Bergson is embarrassed by this relation of Being to Nothingness" (Merleau-Ponty 2003, 58), he writes, concluding that "the true meaning of Bergsonian philosophy is not so much to eliminate the idea of Nothingness as to incorporate it into the idea of being" (Merleau-Ponty 2003, 66). In short (to go very quickly), Merleau-Ponty sees in Bergson a disappointing compromise position: on the one hand the promise of Schelling's nature philosophy fails, there is a falling away from the primordial ground — an "unsticking" of perception "with respect to the real" (Merleau-Ponty 2003, 56) in Bergson's distinction between pure perception and actual perception — and, on the other hand, the full promise of dialectical argument is not fulfilled.

Part of the problem is that Merleau-Ponty neglects to carry over to Bergson the crucial distinction he made in connection with Schelling between a philosophy of time and a philosophy of being. If Bergson's argument in Matter and Memory is hard to follow, it is precisely because his is a philosophy of time. This is what makes it necessary for him to make two important distinctions in one complex and meandering argument: one between image (which he sometimes identifies with matter) and representation (which pertains, at this point in his argument, to perception) and another between the de jure schema of pure perception and real (or actual) perception. To the extent that he deals with them at all, Merleau-Ponty conflates these two arguments.

With Bergson's "here I am in in the presence of images [Me voici donc en présence d'images]" (Bergson 1988, 17; 2012, 11), it is not a question of a perceiving consciousness - a je, for-itself or Nothingness - but rather 
of a me, an image amidst all the other given images. This pronominal position $(m e)$ finds itself not in the presence of an object - an in-itself - but within a totality of other images that exists as an ensemble in flux and in flow. We are not dealing with a subject of consciousness placed before an object, as Bergson makes quite clear in his first example of pure perception: a primitive organism whose perception amounts to physical contact with an image outside itself. Bergson characterises the image, generally, as "being bound up with the totality of all other images [solidaire de la totalité des autres images]" (Bergson 1988, 35; 2012, 32), such that it necessarily acts "through every one of its points upon all the points of all other images" (Bergson 1988, 36), transmitting "the whole of what it receives" (Bergson 1988, 36) and opposing "to every action an equal and contrary reaction" (Bergson 1988, 36). In the case of human beings (and all upper vertebrates) the body is an image and, at the same time, a centre of action (perception involves action, not knowledge). It is living matter.

The image (generally) is embedded temporally as well as spatially; it is continuous with ("se continue dans" (Bergson 2012,32)) the images "which follow it" (Bergson 1988, 35), and "prolonged [prolongeait] those which preceded it" (Bergson 2012, 33; 1988, 36). ${ }^{2}$ To transform the "pure and simple existence" of the image into a representation, Bergson writes, "it would be enough to suppress [supprimer] what follows it [and] what precedes it" (Bergson 2012, 33; 1988, 36). In other words, if pure perception is a de jure schema abstracted from time, it is because extracting an image from time - from the flux and flow of the ensemble of images - is just what pure perception does. It cuts an image out of the temporal continuity of before and after and immobilises it in a representation through an action that marks out a present moment. And this is precisely why, when it comes to actual perception, Bergson will have to say there is no perception without memory. The perceiving body is also an image — one among the many and so participates in the mouvant - the continuity of real time.

To carry out the act of perception that pulls an image outside time it is necessary to make a temporal synthesis, to contract a before and an after. In the case of more complex organisms, perception takes time because it requires the coordination of multiple sensory apparatuses that have varied reach and rhythm. This is where time comes in most explicitly in the case of living beings, i.e., as a hesitation between the receiving of movements or intensities and the returning of them back into the external world. This

2. The tenses are interesting here. 
is what yields the "zones of indetermination" (Bergson 1988, 39) that Bergson speaks of in terms of hesitation and choice, which distinguish living beings from inanimate things that operate mechanically (or automatically) according to laws of nature. Perception becomes something like a projection of our incipient action into a specific site or location, and to this extent it both includes a temporal dimension that pertains to the future and filters the whole of the given to let pass only that part of it that interests our incipient action. And because we are part of the mouvant, the present moment registered by an action of perception will necessarily be covered with a layer of memory. Perception, in other words, has to retain the past so that it can pull itself together and act within an ensemble in flux and flow.

If there is no actual perception without memory (if perception is lined with memory) there is also no actual perception without affect, defined both as what the body absorbs into itself from the outside world and "that part or aspect of the inside of our body which we mix [mêlons] with the image of external bodies" (Bergson 2012, 59; 1988, 58). In either case "affection [affection] must, at a given moment, arise [surgir] out of the image" (Bergson 2012, 55; 1988, 55, italics original); "there is no perception without affection” (Bergson 1988, 58). In this sense actual perception, for Bergson, is a dual operation: it "measures our possible action upon things" and also "the possible action of things upon us" (Bergson 1988, 56). It is this doubling, I think, that underlies the doubling of memory into a receptive memory of the body and a spontaneous image memory that operates through attentive recognition, but this would be a longer discussion (see Guerlac 2019).

It you are familiar with Merleau-Ponty's Nature lectures (or with the work of Jacob von Uexküll) you will have noticed that my selective discussion of Matter and Memory (my sketch of a reading of it) already suggests proximities between Bergson's analysis of perception and what Merleau-Ponty will elaborate as behaviour [comportement] and discuss in connection with the animal body, and with von Uexküll's theory of animal milieu or Umwelt. Indeed, Bergson's characterisation of perception as what "measures our possible action on things and the possible action of things on us" (Bergson 1988, 205) aligns both with von Uexküll's elaboration of the reciprocal relations of animal bodies and Umwelt and with MerleauPonty's analysis of the intertwining relations of comportment.

When we examine Merleau-Ponty's broader argument, we can appreciate that, in spite of his misreading of Bergson in Sartrean terms, the 
perspective he develops in the Nature lectures can usefully reorient our reading of Bergson, bringing out resonances like the one just mentioned that might be of importance to us today. But before we can make this case, we must backtrack a bit. In the introduction to his 1942 La Structure du comportement (Merleau-Ponty 1967), ${ }^{3}$ Merleau-Ponty set comportment up as a matter of relations between consciousness and nature; we remain within a framework of the for-itself and the in-itself. In the Nature lectures, however, he presents comportment as neither thing nor consciousness. No longer primary (as required in a phenomenological analysis) consciousness itself becomes "a type of comportment" (Merleau-Ponty 2003, 167, translation altered). Only one of many forms of behaviour, it "must not be defined from within, from its own point of view, but such as we grasp it across the bodies of others" (Merleau-Ponty 2003, 167, my italics). The notion of comportment (which he borrows from the neuro-embryologist G. E. Coghill and the clinical psychologist Arnold Gesell, with Catherine Strunk Amatuda) enables Merleau-Ponty to escape the alternative of the pour soi and the en soi in the Nature lectures, although he continues to read Bergson through this Sartrean framework. We could say that MerleauPonty misreads Bergson in the Nature lectures to the extent that he is unable to align Bergson's treatment of perception with his own evolving notion of comportment, one that moves beyond the mechanistic understanding of behaviourism toward an (ironically quite Bergsonian) thinking of concrete, meaningful, oriented, indeterminacy that Merleau-Ponty will identify both with Nature and with a concept of life.

Physical things, Merleau-Ponty wrote in his 1942 study, "find the satisfactory explanation of inner unity in mathematical law; the others, which we call living beings [les vivants] present the distinctive characteristic of having a comportment, which is to say that their actions are not comprehensible as functions of a physical milieu and that, on the contrary, the parts of the world to which they react are delimited for them by an inner norm [norme intérieure]" (Merleau-Ponty 1967, 173). As we see in this statement, comportment refocuses our attention on the question of life — comportment is "a category of life" (Merleau-Ponty 1967, 168) and introduces into it the factor of the physical environment of livingness ("the parts of the world to which [living beings] react" (Merleau-Ponty

3. In the subsequent translations, I have translated "comportement" as "comportment" instead of behaviour to avoid associations with behaviourism, from which Merleau-Ponty wanted to distinguish his term. 
1967, 173)) that Merleau-Ponty will elaborate in the Nature lectures through the term Umwelt he borrows from Jacob von Uexküll, who recasts a mechanistic concept of milieu as a reciprocal relation. The organism, Merleau-Ponty writes, "modifies its own milieu according to the inner norm [norme intérieure] of its activity" (Merleau-Ponty 1967, 206). He characterises this inner norm as "a certain type of transitive action that characterises the individual," adding "it measures the action of things on it and delimits its milieu" (Merleau-Ponty 1967, 199). He describes the inner norm as a privileged attitude of a singular type of living being that gives unity to a concrete mode of comportment, which, in turn, gives unity to the evolving, or maturing, organism over time - the unity, we could say, of the living being in its livingness. This is what Merleau-Ponty characterises as the "unity of signification" (Merleau-Ponty 1967, 207) of an organism; he also refers to it as its "vital signification [signification vitale]" (Merleau-Ponty 2003, 161, 173). This idea of signification, he acknowledges, permits him to "conserve the category of life without the hypothesis of a vital force" (Merleau-Ponty 2003, 160). He takes his distance from Bergson in this way.

But Merleau-Ponty will carry forward a certain Bergsonian impulse in the Nature lectures. Summarising the argument of G. E. Coghill in his Anatomy and the Problem of Behaviour (1929), he explains that what makes the unity of comportment meaningful (vitally meaningful, we could say) is time. "We cannot define the animal by its immediate function," he writes, "[...] the apparatus has meaning only for the future" (Merleau-Ponty 2003, 144). This is because "time is characteristic of the Umwelt" (Merleau-Ponty 2003, 173). Comportment unfurls in the organism, which also unfurls its own unity through its comportment: it is necessary, Merleau-Ponty writes, to "examine $[\ldots]$ the animal in time and contemplate $[. .$.$] the$ unfurling of the animal [...] knowing how it takes possession of its body and its milieu" (Merleau-Ponty 2003, 144). Comportment, which refers to a manner (or style) of action is, as Merleau-Ponty writes, "emergent" (Merleau-Ponty 2003, 144); this emergence pertains to the organism, to its comportment and to the animal's Umwelt, that is, the environment of this comportment, which is transformed by it (all of this will be picked up by Georges Canguilhem).

In his 1942 study, Merleau-Ponty complains that the problem with what he calls Bergson's "refined vitalism" (Merleau-Ponty 1967, 171) is that "the relation of the élan vital to what it produces is not thinkable, it is magical" 
(Merleau-Ponty 1967, 171). In the Nature lectures, however, where it is a question of comportment, the question of what is discursively thinkable no longer seems to worry him. He enthusiastically cites von Uexküll's comparison of "the unfurling of an Umwelt" to a "melody that is singing itself" (Merleau-Ponty 2003, 173). Elaborating this figure, he explains that melody, incarnated in the animal, gives us "a particular consciousness of time" (Merleau-Ponty 2003, 174). "In a melody," he writes, "a reciprocal influence between the first and the last note takes place, and we have to say that the first note is only possible because of the last and vice versa [...] it is in this way," Merleau-Ponty concludes, "that things happen in the construction of a living being" (Merleau-Ponty 2003, 174). Melody, of course, was Bergson's privileged figure for qualitative duration in Time and Free Will. And there too it stands for a certain kind of unity that Bergson identifies with the living being. Speaking of the notes of a melody in chapter three of Time and Free Will, Bergson writes that "their totality may be compared to a living being whose parts, although distinct, permeate one another just because they are so closely connected [par l'effet même de leur solidarité]" (Bergson 1913, 100; 2013, 75). He characterises this unity of living beings as "an interconnexion and organisation of elements, each one of which represents the whole, and cannot be distinguished or isolated from it [...]" (Bergson 1913, 101). When Merleau-Ponty characterises the unity figured by melody he echoes Bergson quite precisely: melody, he writes, figures "an adhesion between the elements of the multiple" (Merleau-Ponty 2003, 156).

My main point is not that Merleau-Ponty misreads Bergson and then re-appropriates his thought — substituting von Uexküll's unfurling for Bergson's élan vital. It is not even that Bergson haunts Merleau-Ponty's Nature lectures (where haunting, and specifically the haunting of melody, is a theme). My point is that the path Merleau-Ponty chooses for this reappropriation of features of Bergson's thought — comportment considered in relation to the animal body as an approach to the question of Nature can recalibrate, even reorient, our reading of Bergson to the extent that it articulates time and life in connection with the material world. Specifically, it redirects our attention to the importance of the body in Bergson's thought and, more broadly, to relations between duration and materiality. MerleauPonty's Nature lectures invite us to reconsider Bergson from a perspective that links questions of life or livingness to the issues of time and emergent totality that they imply. 
To sketch this out (which is all I can hope to do here) we would need to reconsider precisely the features of Bergson's analysis in Matter and Memory that Merleau-Ponty neglects in his account of Bergson - memory and affectivity — and to think them together. In Bergson, where time is defined as the registered difference between a before and an after, it is memory that gives us access to time. Bergson usually speaks of consciousness in connection with the registration of this difference - this difference in continuity - that he calls memory. The detour through Merleau-Ponty invites us to read the notion of consciousness in relation to the pragmatics of perception that we evoked earlier. Merleau-Ponty also presents time (the time of emergence that is "characteristic of Umwelt" (Merleau-Ponty 2003, 173)) as a play of before and after that he identifies with melody (echoing von Uexküll explicitly and Bergson implicitly) and characterises through the gesture of unfurling. The important point for our reading of Bergson is not only that this quite Bergsonian conception of time emerges from a consideration of the body, but also that it depends upon reciprocal relations between these active bodies and the immediate environment of their actions - the Umwelt. It calls our attention to the fact that this was implicit in Bergson's account of perception in Matter and Memory when Bergson writes, for example, that "the objects which surround my body reflect [the body's] possible action [l'action possible] upon them" (Bergson 1988,$21 ; 2012,16$ ), and that perception "measures our possible action upon things and thereby, inversely, the possible action of things upon us [mesure notre action possible sur les choses et par là inversement, l'action possible des choses sur nous]" (Bergson 1988, 56; 2012, 57).

Merleau-Ponty's discussion of an organism's comportment in its intertwining relation to the physical environment - the milieu (Umwelt) of this comportment - invites us to reconsider memory in Bergson, not only image memory, but also, and most importantly, the memory of the body as it relates to affectivity: the absorption into the body of some of what it receives from the outside through what Bergson calls a perceptual "shock [ébranlement]" (Bergson 2012, 108, my translation), a gentle intimation of Benjamin's modernist shock. "Behaviour," MerleauPonty writes, "oriented toward an Umwelt begins [...] as soon as we have stimulations that act, not by simple physical presence, but insofar as an organism is disposed to receive them and treat them as signals" (MerleauPonty 2003, 167). This invites us to consider what Bergson calls affect not merely as "intensity," in the wake of Deleuze and Brian Massumi (who 
tend to efface the specificity of livingness in Bergson's thought) but as a specific feature of "living matter [matière vivante]" (Bergson 1988, 28; 2012 , 24), one that pertains to how it holds the past and moves into the future. To the extent that perception, in Bergson, involves action in a temporal field (where the present is on its way to becoming past) the past - the lived time - that it holds onto would consist of its perceptual and affective interactions with its milieu or Umwelt, which could be said to survive in the body. In relation to what he calls the memory of the body in Matter and Memory, Bergson speaks of channels in, and through, the body that register encounters with the outside world and lay down passages of reception which guide potential responses to these encounters, or, we could say, receives signals from the external world. The neurological channels are produced by, and produce, tendencies. We might read these tendencies in relation to what Merleau-Ponty calls inner norms, which, generated in conjunction with specific bodily conformations or complexities, orient (without determining) future actions. The reference to the future that Merleau-Ponty associates with the "unfurling" of comportment (which in turn gives unity to the living being) is to be thought, he says, in terms of a "plurality of phenomena [that] bind together and constitute an ensemble that has meaning" (Merleau-Ponty 2003, 153). This was the thrust of his understanding of von Uexküll's appeal to the melody figure.

"We find models of this idea of totality," Merleau-Ponty writes, "in the world of perception" where "[...] nothing impedes the whole for being other than the sum of its parts without being for all that a transcendent entity" (Merleau-Ponty 2003, 153). The Umwelt unfurls in a movement of signification vitale that bears a certain affinity to Bergson's élan vital. But reading Bergson through Merleau-Ponty's Nature lectures checks any tendency we might have either to read this élan in spiritualist terms or to read it abstractly, with Deleuze, in terms of logics of multiplicities and an ontology of the virtual. Deleuze rhetorically asks:

What does Bergson mean when he talks about élan vital? It is always a case of a virtuality in the process of being actualised [...] a totality in the process of dividing up. Proceeding 'by dissociation and division,' by 'dichotomy', is the essence of life [...] Duration, to be precise, is called life when it appears in this movement (Deleuze 1991, 94-95).

Deleuze abstracts a notion of life from Creative Evolution without reference to Bergson's previous works, having posited a rupture between the earlier works, deemed psychological in nature, and the ontological framework 
initiated in Creative Evolution. If we read Bergson's élan vital through the detour of Merleau-Ponty's Nature lectures, we can construe it more concretely in relation to Time and Free Will and Matter and Memory. The broader terrain of textual reference suggests relation to an environment that intertwines with the unfurling of the movement - the activity or comportment - of a living body, which is not always a human one.

Deleuze's ontological perspective involves "a totality in the process of dividing up," but for Merleau-Ponty in the Nature lectures totality is not the answer - not what is given - but precisely the most important question, a question raised by the articulation of Umwelt and inner norm that come together in comportment. If, on the level of the organism, totality "appears as emergent" (Merleau-Ponty 2003, 145), and therefore cannot be described in physiological terms, "what status," Merleau-Ponty asks, "must we give totality?" (Merleau-Ponty 2003, 145). His reply should not entirely surprise us: "Such is the philosophical question [...] which is at the centre of this course on the idea of nature, and maybe of the whole of philosophy" (Merleau-Ponty 2003, 145). The intertwining that he locates in the reciprocal relations between organism and Umwelt extends to an overlapping (or intertwining) of relations between the Umwelten themselves, relations that compose what he calls "nature" as, precisely, "the Umwelten of Umwelten" (Merleau-Ponty 2003, 177). What is more, this emergent totality is oriented - it has, as it were, its own inner norm - in that, as Merleau-Ponty writes, "the envelopment of an Umwelt by another is required for its own" (Merleau-Ponty 2003, 177, my emphasis). We could say that the movement of totalisation is oriented from within, that it occurs in relation to something like tendencies or inner norms, which in turn are related to specific material sites. For Merleau-Ponty himself, the intertwining that runs, over time, from the simplest organism all the way up to, and through, what he calls Nature is just what the figure of the melody that sings itself conveys.

Returning now to Bergson, we must mention one more refinement of the melody figure, one that our detour through Merleau-Ponty might help us better appreciate. In Duration and Simultaneity Bergson extends the reach of duration beyond the individual inner experience of qualitative duration, figured by melody in Time and Free Will, and even beyond the evolutionary framework he presents in Creative Evolution (the élan vital), to what he calls a "duration of the universe" (Bergson 1999, 31). In this context time becomes explicitly "the very stuff of our existence and of all things" (Bergson 1999 , 43, italics mine), a formulation that ties the living being to its physical 
surroundings in a temporal ontology. We note the resonance with Schelling here, since Bergson refers to "real time" as time "perceived and lived" (Bergson 1999, 33). But at this point Bergson also begins to sound a bit like Merleau-Ponty, if we read backwards from him. Bergson writes:

To each moment of our inner life [...] corresponds a moment of our body and of all environing matter that is 'simultaneous' with it; this matter then seems to participate in our conscious duration. Gradually, we extend this duration to the whole physical world, because we see no reason to limit it to the immediate vicinity of our body. The universe itself seems to us to form a single whole; and if the part that is around us endures in our manner, the same must hold, [...] for that part which, in turn, is surrounded, and so on indefinitely. Thus is born the idea of a duration of the universe (Bergson 1999, 31).

This account of the "duration of the universe" (Bergson 1999, 31) aligns with Merleau-Ponty's depiction of nature as the "Umwelt of Umwelten" in a process of unfurling. It is an argument by analogy (a corrective to the practices of intelligence which have evolved to further the instrumental interests of humans, as Bergson argues in Creative Evolution) that brings us back around to the melody figure - but with a difference. Bergson compares the "basic time" (Bergson 1999, 30) involved in the duration of the universe - a "physical time" (Bergson 1999, 32) - to listening to a melody. But this time, he insists that, as we listen, we must "do away with the distinctive features of sound itself, retaining of it only the continuation of what precedes into what follows and the uninterrupted transition, multiplicity without divisibility and successions without separation" (Bergson 1999, 30). This, he writes, is how we would "rediscover basic time," how we would pass from "inner time to the time of things" (Bergson 1999, 30, my italics).

Does the time of the universe - basic time, or the time of things eradicate the reference to consciousness, as Deleuze suggests? No. "It is impossible," Bergson continues, "to conceive a connecting link between the before and after" - i.e., duration - "without an element of memory or consciousness" (Bergson 1999, 33). But he adds this crucial point of clarification: "We may perhaps feel averse to the use of the word 'consciousness' if an anthropomorphic sense is attached to it. But to imagine a thing that endures there is no need to take one's own memory and transport it, even attenuated, into the interior of the thing" (Bergson 1999, 33), no need, he clarifies, to presume "a human character of memory" (Bergson 1999, 33). "Indeed," he adds emphatically, "it is the opposite course we must follow" (Bergson 1999, 33). Instead of human memory, 
what is at stake here is the minimal consciousness that we presuppose in an act of perception or registration of the real, such as we find even in primitive organisms (as in the example of the perception already noted). This is what Bergson refers to as "elementary memory," which is impersonal — we could call it a memory of the universe. It is "memory within change itself" (Bergson 1999, 30) that Bergson identifies with transition, as between the frames of the cinematograph that he proposes as a figure for intelligence in Creative Evolution. Even here (as in von Uexküll's theory of Umwelt) there is a requirement of perception: "We require the property of being perceived or perceptible for everything held up as real" (Bergson 1999, 46). If, as Bergson affirmed in Matter and Memory, there is no actual perception without memory - "in actuality [en fait] there is no perception which is not full of [imprégnée de] memories" (Bergson 1988, 33; 2012, 30) the reverse also appears to be the case : there is no memory — indeed no time - without some mode of perception. Melody (now without qualities or the nuances of sound) is the way Bergson writes this elementary and impersonal memory of things that connects a before and an after - this "duration of the universe" (Bergson 1999, 31).

What the detour through Merleau-Ponty's examination of Nature introduces into our reading of Bergson is, first of all, the explicit focus on life as it reaches beyond human life. Umwelt, through which MerleauPonty constructs his concept of Nature as an Umwelt of Umwelten, is, we remember, a category of life. Claude Bernard was one of the first to insist that the categories of life and milieu go together. Of course, Bergson famously treats life quite explicitly from the perspective of evolution in Creative Evolution, where it is a question of life forms. For contemporary readers however, Deleuze's judgement that this work marks a turning point in Bergson's work - a shift from a psychological to an ontological framework - has tended to efface our appreciation of the importance of life in all Bergson's writings. What the detour through Merleau-Ponty reinforces is the link between the question of life and time (which even the appeal to ontology, as an ontology of being, tends to arrest, as distinct, say, from the ontogenesis Gilbert Simondon proposes in a spirit much closer to Bergson). ${ }^{4}$ We can't think Umwelt without time. But what it also reinforces, perhaps even more importantly, is the link between life and materiality, with which it is actively intertwined — the relations, we could

4. For the notion of ontogenesis see Simondon (2017); he characterises it as a becoming of being where the becoming modifies it. For its relation to Bergson, see Guerlac (2021). 
say, between living matter and nonliving matter. Alerted to this possibility, we can attend to Bergson when he writes that "something of our body and environing matter enters into our perception" (Bergson 1999, 31, my emphasis). We don't have to argue about whether, as Bergson seemed to say in his early work, time only pertains to living beings. We don't have to argue about the limits between the living and the nonliving categorically (which is to say abstractly). We can consider these questions concretely, which is to say in relation to a dynamic scale of relations rather than a categorical opposition. This is Bergson's approach, whether it is a question of the two extremes of mental life he proposes in Matter and Memory action and dream - or the two modalities of understanding he opposes in Creative Evolution - intelligence and intuition - while appealing to all the degrees in between the two.

Time, life (human, animal and plant) bodies of all sorts and the duration of the universe - these are the questions we need to address today, in the face of the fragility of our planet. The detour through Merleau-Ponty's Nature lectures invites us to reconsider the dimension of natural history that, as Philippe Soulez indicated, was separated out from the concerns of human history by a generation of $20^{\text {th }}$ century dialectical thinkers for whom "a philosophy of the history of nature that does not yield a human philosophy [was] unthinkable" (Soulez 1983, 5). Perhaps just the reverse is true today: we cannot think a human philosophy without learning to think in more than human terms as well. In the context of our extinction crisis, which reaches across the globe, we begin to hear other discourses Native American, or other indigenous voices, for example - that speak with ease and authority about life as it passes through all living beings, and about how to protect it. Can Bergson help us find our way into this discussion? In 1932 Bergson asked us to decide if we wanted to go on living. The question still stands, and Bergson still has something to say to us about it. Are we going to continue to deny or ignore the facts about our planet? Are we are going to place our hopes in the same human logics that contributed to the crisis we face, and capitulate to the seductions of technological, or piecemeal geo-engineering, solutions to the planetary crisis? Or are we going to think duration instead of development and learn to read duration as a duration of the universe that puts life and matter in dynamic relation to one another through dynamics of livingness? 


\section{Bibliography}

Benjamin, Walter. 1968. "On Some Motifs in Baudelaire." In Illuminations, edited by Hannah Arendt. New York: Schocken Books.

Bergson, Henri. 1913. Time and Free Will. An Essay on the Immediate Data of Consciousness. Translated by F. L. Pogson. London: George Allen \& Co.

Bergson, Henri. 1988. Matter and Memory. Translated by W. Scott Palmer and N. M. Paul. New York: Zone Books.

Bergson, Henri. 1999. Duration and Simultaneity: Bergson and the Einsteinian Universe. Translated by Leon Jacobson. Manchester: Clinamen Press.

Bergson, Henri. 2012. Matière et mémoire. Essai sur la relation du corps à l'esprit. Paris: Presses universitaires de France.

Bergson, Henri. 2013. Essai sur les données immédiates de la conscience. Paris: Presses universitaires de France.

Deleuze, Gilles. 1991. Bergsonism. Translated by Hugh Tomlison and Barbara Habberjam. New York: Zone Books.

Guerlac, Suzanne. 2019. "Bergson, the Time of Life and the Memory of the Universe. In Interpreting Bergson. Critical Essays, edited by Alexandre Lefebvre and Nils F. Schott, 104-120. Cambridge: Cambridge University Press.

Guerlac, Suzanne. 2021. "Livingness, Information, and the Really Real." Theory \& Event 24(1): 131-156.

Horkheimer, Max. 1983. "La Métaphysique Bergsonienne Du Temps." Translated by Philippe Joubert. L'homme et La Société 69-70: 9-29.

Massumi, Brian. 2018.99 Theses on the Revaluation of Value: A Postcapitalist Manifesto. Minneapolis and London: University of Minnesota Press.

Merleau-Ponty, Maurice. 1967. La Structure Du Comportement. Paris: Presses universitaires de France.

Merleau-Ponty, Maurice. 2003. Nature. Course Notes from the Collège de France. Compiled and with Notes by Dominique Séglard. Translated by Robert Vallier. Evanston, Illinois: Northwestern University Press.

Read, Rupert, and Samuel Alexander. 2019. This Civilisation Is Finished. Conversations on the End of Empire - and What Lies Beyond. Melbourne: Simplicity Institute.

Simondon, Gilbert. 2017. L'Individuation à la lumière des notions de forme et d'information. Paris: Millon. 


\title{
Soulez, Philippe. 1983. "Présentation d'un article inédit en français de Max Horkheimer sur Henri Bergson.” L'Homme et la société 69-70: 3-9.

\author{
Whitehead, Alfred North. 1934. Nature and Life. Cambridge: Cambridge \\ University Press.
}

Suzanne Guerlac is Professor in the Graduate School at UC Berkeley. She is an expert of French philosophy and literature. Among her several contributions to the philosophy of time and life in Bergson, Valéry and Derrida, she is the author of Thinking in Time: An Introduction to Henri Bergson(Cornell UP 2006), and of Proust, Photography and the Time of Life : Ravaisson, Bergson, Simmel (Bloomsbury 2020).

\begin{abstract}
Can it be productive to consider misreadings of Bergson? We recall Max Horkheimer's critique of Bergson and reconsider it from the vantage point of MerleauPonty in a trajectory that moves us away from the Horkheimer/ Bergson alternative and also from the Bergson-Deleuze hybrid. In his Nature lectures Merleau-Ponty misreads Bergson when he explicitly takes up his thought, but he does so within a broader argument that is not only haunted by Bergson but, more importantly, can refresh and enliven our reading of him, giving us a new appreciation for what Bergson called "the duration of the universe." Our attention is redirected to imbrications of time and life in Bergson and to relations between matter and living matter - the kind of dynamic relations MerleauPonty will evoke through Umwelt as it pertains to a more than human universe. If a philosophy predicated on the work of the negative propelled a century of social change, Bergson can help us to learn to think livingness in the face of an all too fragile planet.
\end{abstract}

Keywords: Henri Bergson, Maurice Merleau-Ponty, nature, livingness, duration of the universe, Umwelt.

Résumé : Peut-il être productif de prendre en considération les lectures erronées de Bergson ? Nous rappelons la critique de Bergson par Max Horkheimer et la reconsidérons du point de vue de Merleau-Ponty dans une trajectoire qui nous éloigne de l'alternative Horkheimer/Bergson et aussi de l'hybride Bergson-Deleuze. Dans ses conférences sur la nature, Merleau-Ponty interprète mal Bergson lorsqu'il reprend explicitement sa pensée, mais il le fait dans le cadre d'une argumentation plus large qui n'est pas seulement hantée par Bergson mais, plus important encore, qui peut nous en rafraîchir et animer la lecture, en nous donnant une nouvelle appréciation de ce que Bergson appelait "la durée de l'univers." Notre attention est redirigée vers l'imbrication du temps et de la vie chez Bergson et vers les relations entre la matière et la matière vivante - le genre de relations dynamiques que Merleau-Ponty évoquera à travers l'Umwelt dans sa relation avec un univers plus qu'humain. $\mathrm{Si}$ une philosophie fondée sur le travail du négatif a propulsé un siècle de changement social, Bergson peut nous aider à apprendre à penser le vivant face à une planète trop fragile.

Mots-clés : Henri Bergson, Maurice-Merleau-Ponty, nature, vivant, durée de l'univers, Umwelt. 
